\title{
MARTIAL ARTS MARKET DEMAND: TEST AND VALIDATION OF A MODEL ON THE BRAZILIAN JUDO CONTEXT
}

\section{CLÁUDIO DAMACENA}

$\mathrm{PhD}$ in Business, Universidad de Cordoba (UCO).

Professor at the Department of Marketing,

Pontifícia Universidade Católica do Rio Grande do Sul (PUC-RS).

Avenida Ipiranga, 6681, Partenon, Porto Alegre - RS - Brasil - CEP 90619-900

E-mail: claudio.damacena@pucrs.br

\section{VITOR CESAR MOREIRA}

Master's Degree in Business and Administration from the Department of Marketing,

Pontifícia Universidade Católica do Rio Grande do Sul (PUC-RS).

Professor at the Department of Physical Education,

Centro Universitário Fundação Assis Gurgacz (FAG).

Av. das Torres, 500, Loteamento FAG, Cascavel - PR - Brasil - CEP 85806-095

E-mail: vitor@fag.edu.br

\section{MARTIN DE LA MARTINIÈRE PETROLL}

$\mathrm{PhD}$ in Business, Federal University of Paraná (UFPR).

Professor at the Department of Administration Sciences,

Federal University of Santa Catarina (UFSC).

AC Cidade Universitária, Trindade, Florianópolis - SC - Brasil - CEP 88040-970

E-mail: martin.petroll@ufsc.br 


\section{ABSTRACT}

Purpose: Deepening the knowledge about factors which determine and explain the reasons and intentions of judo practitioner's consumption, investigating how their demands on the sport relate to the perceived benefits, restrictions, value, satisfaction and commitment to judo.

Originality/gap/relevance/implications: We tested a theoretical model that specifies the direct and indirect relations between market demand, perceived benefits, restriction and value, as well as the satisfaction and commitment of a judoist with the martial arts in a different country and sport of the original study.

Key methodological aspects: We conducted a survey with 328 judoists in Brazilian gyms. We analysed the data with the software PLSmart which uses the Partial Least Square method.

Summary of key results: We found that market demands positively affect the perceived benefits and value and the judo members' satisfaction and commitment. We also discovered that the perceived benefits positively affect the perceived value, which positively triggers satisfaction, this way increasing the practitioner's commitment.

Key considerations/conclusions: The results found in this study reinforce the relations proposed in Kim's original study showing a certain solidity in the explaining power of the underlying theory. But there are some peculiarities, like different perceived benefits for practicing judo as well as intrapersonal restrictions which discourages getting involved in judo. Finally, this article reinforces Sheth's (2011) affirmation that marketing is modified according to the context in which it is inserted, in this case, in the sport of judo in Brazil.

\section{KEYWORDS}

Market demand. Perceived benefits. Constraints and value. Satisfaction. Commitment. 


\section{INTRODUCTION}

Martial arts are practiced all over the world. For example, judo, which has been an Olympic sport since 1964, is practiced by more than eight million people in about 180 countries, according to the International Judo Federation (2014). In Brazil, there are about one million judo practitioners, and it is the sport in which the country has won the most Olympic medals (22 medals: four gold, three silver, and 15 bronze) (CBJ, 2017) and the third most Paralympic medals (22 medals: four gold, nine silver, and nine bronze), after track and field and swimming (BRASIL2016; 2017; CBJ, 2017). Therefore, there is a significant market for judo practitioners in Brazil, especially since the Rio Olympic Games 2016, where Brazil won three medals (one gold and two bronze) and the Paralympics (four silver medals) (CBJ, 2017). As a result, interest in the sport increased considerably, making judo the most popular martial art in Brazil (CBJ, 2017).

According to the Brazilian Judo Confederation (CBJ, 2015), there are more than 1,000 judo training centers throughout the country and, according to the Brazilian Academies Association (ACAD, 2017), more than 30,000 academies across all sports. Managers have to deal with fierce competition among judo practitioners, as well as among the many other rival training centers competing for consumers. The general academies market was worth USD 2.5 billion dollars in 2014 (ACAD, 2017). Therefore, understanding the demands of the market enables these managers to create effective marketing strategies in this broad and competitive segment, as well as in the martial arts niche (Zhang, Lam, \& Connaughton, 2003).

Nevertheless, as in other martial arts, such as tae kwon do (Kim, Zhang, $\&$ Ko, 2009), the judo training center manager usually worries only about practitioners' monthly fees, and knows little about how to keep those members. According to the National Sport Diagnostic, conducted by the Brazilian Sport Ministry (Ministério do Esporte, 2014), in 2013, 54.1\% of the Brazilian population practiced sports or physical activities. One of the main reasons the remaining $45.9 \%$ do not do so is a lack of time $(69.8 \%)$. Therefore, there is an opportunity to better understand this group, and to encourage them to take part in sport and judo.

The success of the Rio Olympic Games 2016 means there will likely be an increase in demand for judo, as well as an increase in the number of training centers. For example, after the London Olympic Games 2012, there was an increase in people participating in track and field and cycling, two disciplines that won a number of medals (Hammond, 2016). According to Hammond, 
[...] at least in theory, the 'demonstrative effect' of sporting events to encourage the practice of that sport may inspire those who already do sport to do it more often, as well as those who have retired to return to practice and, finally, encourage people to try sports they have never done.

This effect happened in Brazil in 2013, with the massive increase in popularity of mixed martial arts (MMA), which saw participation in Brazilian academies rise by $80 \%$ (Ferreira, 2013). On the other hand, a lack of motivation to continue practicing judo after the Olympic Games are completed is also expected, along with the closing of centers. England had a similar experience after it had hosted the 2012 Games (Hammond, 2016).

Thus, elements such as market demand, perceived (psychological, social, and physical) benefits, (intrapersonal, interpersonal, or structural) restrictions, and value (benefits minus restrictions) are considered to influence consumers' behavior and, therefore, must be understood by sports managers (McDougall \& Levesque, 2000; Eggert \& Ulaga, 2002; Johnson, Sivadas, \& Garbarino, 2008), who can then learn to use judo practitioners' behavior to predict their length of stay in the martial arts (Snoj, Korda, \& Momel, 2004; Woodruff, 1997).

In addition to the aforementioned elements, in judo, consumers' satisfaction and commitment are extremely important to managing the relationship between managers and the sport's practitioners effectively, to everyone's benefit (Garbarino \& Johnson, 1999).

Thus, it is understood that there is a relatively unexplored market in terms of understanding judo participants' behavior, despite the already considerable number of practitioners. According to Ko and Yang (2012), the martial arts are now believed to be an interesting business opportunity. However, in order for this to happen, from a practical marketing perspective, Cianfrone et al. (2015, p. 94) state the following: "Marketing research on these pull factors can influence sport managers by knowing how, and the extent to which they may entice a consumer response. Sport marketers could then utilize this information to develop marketing strategies based on identifying the factors that influence attendance".

However, few studies have sought to understand martial arts consumers' behavior. Kim (2010) found that perceived benefits and restrictions are both affected by the market's demand, while perceived value is affected by the sports member. He also found that demand for martial arts is related to members' satisfaction and commitment. 
There are still gaps in the relationships among market demand, benefits or restrictions, value, satisfaction, and commitment in the context of the various martial arts, including judo. Furthermore, studies that have examined the aforementioned constructs in the context of sport have focused on industrialized countries, or developed countries (Burgess \& Steenkamp, 2006). According to the latter authors, as well as Sheth (2011), it is essential for marketing science and practice that more studies be conducted in so-called emerging or developing countries, such as Brazil. Such studies are necessary because these countries present socioeconomic, demographic, cultural, and regulation peculiarities that challenge the conventional understanding of the constructs and their relations, which are based on developed countries. In addition, marketing is a subject that is modified according to the context in which it is inserted (Sheth, 2011).

The current study aims to identify the prior factors that determine and explain why people, as consumers, engage in such sport. Furthermore, Kim's measurement scale (2010) is adapted to investigate how their demands relate to perceived benefits, restrictions, value, satisfaction, and commitment in Brazil.

Thus, instead of searching for "the convenience in our own yard" (Burgess \& Steenkamp, 2006), this study contributes to marketing science and practice literature by questioning the global use of the aforementioned constructs, and examining the generalizations based on developed countries in the context of developing countries (Burgess \& Steenkamp, 2006), such as Brazil.

Finally, this type of research is critical to the advancement of science, and increases the robustness of the theory (Easley, Madden, \& Dunn, 2000) on market demand, in the context of judo in Brazil. The study identifies characteristics that differ to those identified by Kim (2010), such as practicing judo for personal growth, emphasizing the physical and psychological benefits of judo, but also giving structural and intrapersonal restrictions as factors discouraging getting involved in judo. Furthermore, other characteristics are identified that agree with those of Kim (2010), such as the positive relation between market demand, perceived value, member satisfaction, and member commitment.

\section{REVIEW OF LITERATURE}

A determining factor in satisfying consumers' needs is being aware of, and meeting their expectations, which then increases market demand (Zhang et al., 1995). Thus, market demand is defined as consumers' expec- 
tations about a product's features (Zhang, Lam, \& Connaughton, 2003). In other words, market demand is a set of attraction factors associated with a sport product, which an organization can offer to new and existing consumers (Kim, Zhang, \& Ko, 2009; Zhang, Lam, \& Connaughton, 2003; Zhang et al., 1995). Therefore, being aware of the market demand means the organization can understand consumers' expectations and, thus, formulate effective marketing strategies (Zhang, Lam, \& Connaughton, 2003; Zhang et al., 1995).

In order to do so, we need to identify the perceived benefits of using a product or service, such as the integration and combination of physical and service features, as well as technical support, which can be tangible or intangible, and inherent or extrinsic (Monroe, 2003; Snoj, Korda, \& Mumel, 2004). That is, a benefit is what the consumer considers to be an advantage of using a service or product over using competing alternatives or, more simply, the gains obtained from an exchange with a company (Zeithaml, 1988).

Therefore, the consumer aims to benefit from the result of the decision-making process concerning a product or service (Monroe, 2003). Needless to say, this is also true of the martial arts. Studies conducted by Fuller (1988), Lakes and Hoyt (2004), and Stefanek (2004), among others, state that the benefits to martial arts practitioners may be psychological, social, or physical. Psychological benefits include anxiety and depression reduction, emotional stability, independence, stress relief, enthusiasm, self-confidence, leadership capacity, taking responsibility for their actions, self-regulation, self-control, body control, discipline, and improvements in self-esteem. Social and physical benefits include the development of technical abilities and tactics, health improvements owing to reduced obesity, personal well-being, and physical aptitude, such as cardiopulmonary and muscular resistance and agility and flexibility.

Thus, as identified by Kim (2010), a positive relationship between market demand and the benefits perceived by the judo practitioners is established based on the following hypothesis:

$\mathrm{H}_{1}$ : Judo market demand positively affects the benefits perceived by its practitioners.

Then, we have perceived restrictions, which refer to what is given as an effort in the exchange of something you wish (Murphy \& Enis, 1986). In other words, a restriction limits preference formation, and may inhibit participation and pleasure in certain activities (Jackson, 1997).

The restrictions perceived by consumers that hamper their consumption may be intrapersonal, interpersonal, or structural. The first refers to prefe- 
rences and interests, such as stress, religion, depression, the ability of self-perception, and their reference group attitudes. The second refers to social relationships or the relationships between partners within a social group. The last refers to organizational and structural functions, such as a lack of financial resources and/or time, a perception of low energy consumption, lack of discipline, injuries, health problems, or the practitioner's lack of ability (Shaw, Bonen, \& McCabe, 1991; Jackson, Crawford, \& Godbey, 1993).

That the above-mentioned restrictions inhibit martial arts practitioners' participation has been confirmed by Kim, Zhang, and Ko (2009) and Kim and Trail (2010), among others. As a result, Snoj, Korda, and Mumel (2004) and Woodruff (1997) highlight that perceived benefits and restrictions both play a critical role in explaining market demand and, consequently, consumers' behavior, which helps us to predict whether people intend to remain as participants. Thus, the following hypothesis is established:

$\mathrm{H}_{2}$ : Judo market demand negatively affects the restrictions perceived by its members.

Another construct important to understanding judo practitioners' behavior is perceived value. Zeithaml, Berry, and Parasuraman (1990) and Ulaga and Chacour (2001) define perceived value as the general evaluation by the consumer of the utility of a service or product, based on the perception of what is offered and what is received. Therefore, perceived value is the relationship between the benefits and restrictions perceived by the consumer and experienced before, during, or after using the product or service (Zeithaml, 1988; Woodruff, 1997).

As proposed by Kim (2010), the benefits and the restrictions perceived by judo members are considered to reflect the value they perceive. Thus, the following hypothesis is proposed:

$\mathrm{H}_{3}$ : Judo market demand positively affects the value perceived by its members.

Satisfaction helps marketers understand how to use consumers' responses and feedback to retain clients (Cronin, Brady, \& Hult, 2000) and their loyalty (Fornell et al., 1996). This construct is defined as the result or answer to a consumption experience and an evaluation of how well a product, service or benefit satisfies their needs, desires, or goals (Tse \& Wilton, 1988).

When it comes to martial arts, some studies measure satisfaction using consumers' previous experiences. The cumulative result of the evaluations 
is considered a determining factor in member retention and acquisition (Gotlieb, Grewal, \& Brown, 1994). The success of a martial arts program is determined by how well it satisfies consumers with a quality service, because high levels of satisfaction contribute to preventing and reducing problems with clients.

Therefore, it is logical to consider that market demand, measured using consumers' previous perceptions of the benefits versus restrictions of judo, will impact their satisfaction. Thus, we have the following hypothesis:

$\mathrm{H}_{4}$ : Judo market demand positively affects the satisfaction of its members.

During their lifetime, people develop bonds with others, groups, and organizations. Clearly, commitment is considered an important construct for the maintenance of long-term successful relationships. Consequently, relationships, especially within the services segment, are built on mutual commitment (Morgan \& Hunt, 1994).

Some believe that commitment can be understood as the continuous desire to keep a valuable relationship (Moorman, Zaltman, \& Deshpandé, 1992), an exchange of belief between the parts involved that this relationship is important enough to require using the maximum effort to keep it (Morgan \& Hunt, 1994), or the quality, satisfaction, value, and effect on consumers' behavior intentions (Cronin, Brady, \& Hult, 2000).

Thus, in the martial arts, commitment may be affected by the demand for a product or service, yielding the following hypothesis:

$\mathrm{H}_{5}$ : The Judo market demands affect positively the commitment of its members.

According to Monroe and Krishnan (1985), a positive perception of value requires the perceived utility (benefit) to be higher than that sacrificed (restrictions). That is, the more positive the benefits, as perceived by the consumer, the higher the value will be.

An important argument proposed by the current study is that the benefits and restrictions perceived by martial arts members have consequences, and reflect the value perceived by the members. From this perspective, the consumer acquires products and services that provide a higher cost/benefit value. In the models of perceived value proposed by Dodds, Monroe, and Greal (1991) and Zeithaml (1988), the perception of the benefits of a company's offering is positively related to the perception of value. In addition, the present research proposes the following hypothesis: 
$\mathrm{H}_{6}$ : The benefits of judo, as perceived by its members, positively affect their perceptions of its value.

As mentioned previously, perceived restrictions are considered critical to predicting consumers' behavior, mainly for the sports management, because they can prevent people from participating in the sport. For instance, Snoj, Korda, and Mumel (2004) found that perceived restrictions may result in negative perceptions of value. Then, Tam (2004) noted that perceived restrictions, such as money and time, have a negative effect on perceived value and, therefore, on consumers' behavior. Thus, we have the following hypothesis:

$\mathrm{H}_{7}$ : The restrictions perceived by judo members negatively affect their perceived value of judo.

Then, there is a difference between satisfaction and perceived value, because satisfaction can occur immediately after a purchase, whereas perceived value is usually determined at the moment of acquisition (Sweeney \& Soutar, 2001). The studies of McDougall \& Levesque (2000) and Parasuraman \& Grewal (2000) found that perceived value has a positive influence on consumer satisfaction in service environments, even triggering changes in behavior intentions. Therefore, perceived value affects clients' satisfaction and their behavior intentions (Cronin, Brady, \& Hult, 2000; Eggert \& Ulaga, 2002; Fornell et al., 1996; Tam, 2004; Woodruff, 1997). Thus, the following hypothesis is established:

$\mathrm{H}_{8}$ : The value perceived by judo members positively affects the satisfaction they derive from the sport.

Finally, several studies have examined how satisfaction may impact consumers' behavior (Eggert \& Ulaga, 2002). For example, Johnson, Sivadas, and Garbarino (2008) affirm that a satisfied consumer tends to be more committed to the product or service. That is, commitment behavior is the result of satisfying a consumer's needs or desires. Thus, meeting the market's demand results in satisfaction, which triggers greater commitment to the acquired product or service. This results in our final hypothesis:

$\mathrm{H}_{9}$ : Judo members' satisfaction positively affects their commitment to the sport.

Figure 1 illustrates the nine hypotheses presented here. 


\section{(Figure 1)}

THEORETICAL MODEL

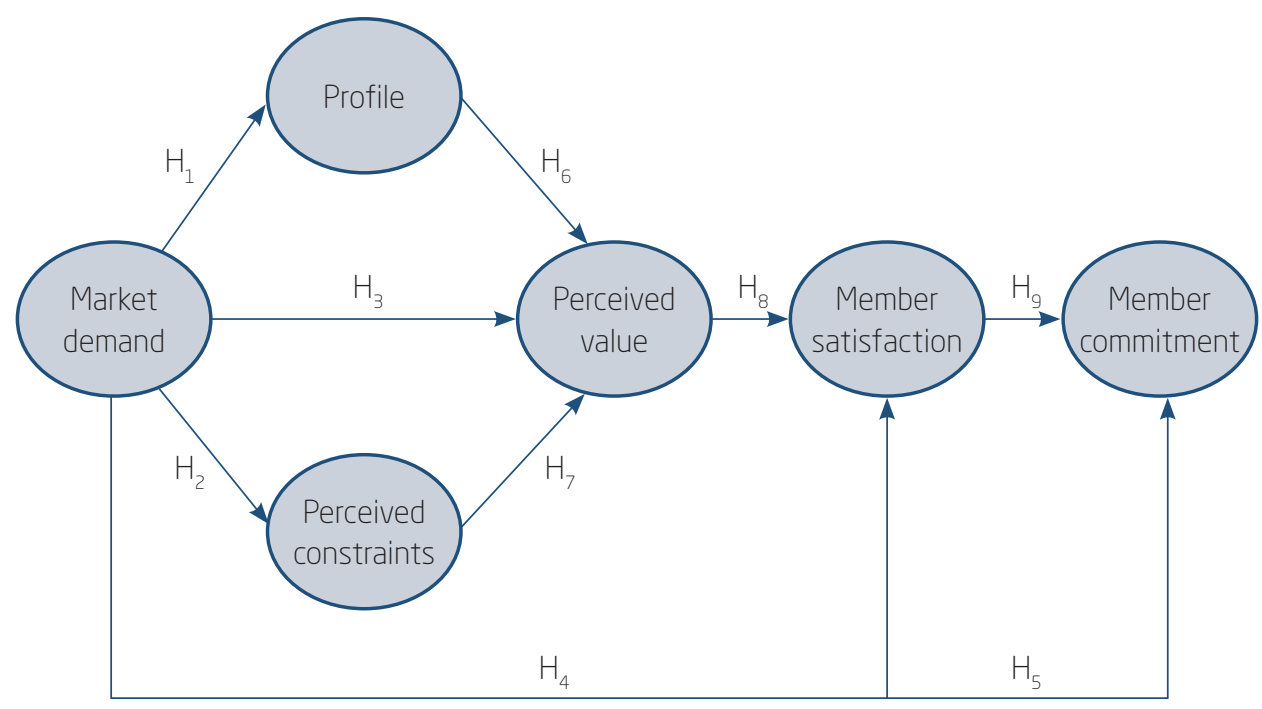

Source: Adapted from Kim (2010).

\section{METHODOLOGY}

The constructs studied here are the same as those operationalized by Kim (2010). Therefore, the data collection instrument consists of 114 indicators (See Table 1), which measure the following: 1. market demand (62 items, divided into seven sub-factors); 2 . perceived benefits (12 items, divided into two sub-factors); 3 . perceived restrictions (22 items, divided into three sub-factors); 4 . perceived value (11 items, divided into four sub-factors); 5. satisfaction (three items in a single factor); and 6. commitment (four items in a single factor). All are measured using a seven-point Likert Scale.

We first translated Kim's original study scales (2010) from English to Portuguese using a back translation system. A qualified professional completed the first translation and, then, a second person translated the text back to English, enabling us to compare the two versions. In addition, we were careful to adapt the items on the original scale, based on tae kwon do in the United States, to the reality of judo in Brazil. In order to do so, the collection instrument was sent to a linguistic specialist and a judo black 
belt sensei (master), who first evaluated the linguistic terms, followed by the technical terms. Next, the suggested alterations were validated. Content validation was carried out by two administration professors. Lastly, after making various alterations, we constructed the final version of the collection instrument. This was then sent to a pre-test involving 20 judoists from different parts of a southern state of Brazil. The pre-test did not find any inconsistencies.

Next, data were collected from 355 judo members. The questionnaire was disseminated to training centers in several cities in Paraná (Brazilian state). Of the 355 completed questionnaires, 328 were considered valid, and showed the following characteristics: $75.6 \%$ are male; $49.1 \%$ are young people ranging from 18 to 26 years of age; $56.7 \%$ are single; $52.4 \%$ are graduate students; $61.4 \%$ receive a gross family monthly income over BRL 2,000.00; $64 \%$ attend a private training center; $62.5 \%$ have practiced judo for more than nine years; $43.3 \%$ have been practicing in the same training center for more than seven years; $94 \%$ attend gym at least twice a week; $80 \%$ spend between one and two hours per day where they practice the sport; $43 \%$ belong to an intermediate graduation (i.e., orange to brown belts); $78 \%$ found out about their training center through friends or acquaintances; and $66.2 \%$ spend up to BRL 1,200.00 on judo per year.

\section{RESULTS}

Before conducting the hypothesis tests, the constructs and the model were evaluated for reliability and validity, which we call measurement model evaluation.

\subsection{Measurement model evaluation}

The analyses were conducted using PLSmart, which uses the partial least squares method. This method has two important advantages over traditional methods of modeling structural equations (Hair et al., 2014). The first is the possibility of analyzing relatively small samples, given the number of parameters estimated in the model. The second is the possibility of analyzing data that are not normally distributed, a common characteristic in most scientific studies in the Social Sciences field (Hair et al., 2009).

The evaluation of reliability, validity, and multicollinearity indicated that several items should be excluded because they present a very low load. 
Thus, of the 114 indicators, 27 were excluded, as shown in Table 1. The results show that in the general measurement model, the alpha coefficient $(\alpha)$ of the constructs and their latent factors showed a high level, ranging from 0.71 to 0.93 . As recommended in the literature, convergent validity is obtained once the individual factor loads are all above 0.6 , and the average variance extracted (AVE) figures from the constructs are above 0.50 .

Compound reliability achieved rates over 0.70 in all constructs, proving that these are reliable measures. The alpha coefficients and the compound reliabilities of the constructs satisfaction and commitment were $0.88-0.93$ and $0.84-0.90$, respectively. The AVE was 0.81 for the satisfaction construct and 0.69 in the case of commitment.

\section{(Table 1)}

LOADINGS OF VARIABLES AND MEASURES OF RELIABILITY AND VALIDITY OF SCALES

\begin{tabular}{l|c|c|c|c|c}
\hline \multicolumn{1}{c|}{ Factors and items } & CR & $(\lambda)$ & $(\alpha)$ & AVE & $\begin{array}{c}\text { Exclued } \\
\text { items* }\end{array}$ \\
\hline $\begin{array}{l}\text { Market Demand - Personal Improvement Activities } \\
\text { Improving self-discipline (PIA1) }\end{array}$ & 0.93 & & 0.93 & 0.54 & \\
\hline Improving patience (PIA2) & & 0.671 & & & \\
\hline Learning to be humble (PIA3) & & 0.667 & & & $x$ \\
\hline Explore individual potentials (PIA4) & & 0.749 & & & \\
\hline Building character (PIA5) & & 0.695 & & & \\
\hline Fostering a positive attitude (PIA6) & & 0.780 & & & \\
\hline Improving self-confidence (PIA7) & & 0.777 & & & \\
\hline Improving social skills (PIA8) & & 0.787 & & & $\times$ \\
\hline Improving self-concept (PIA9) & & 0.751 & & & \\
\hline Increasing personal pride (PIA10) & & - & & & \\
\hline Developing respect for other people (PIA11) & & 0.726 & & & \\
\hline Developing a strong work ethic (PIA12) & & 0.749 & & & \\
\hline Improving leadership skills (PIA13) & & 0.750 & & & \\
\hline Developing a code of honor (PIA14) & & & & \\
\hline
\end{tabular}




\section{(Table 1 (Continuation)) \\ LOADINGS OF VARIABLES AND MEASURES OF RELIABILITY AND VALIDITY OF SCALES}

\begin{tabular}{|c|c|c|c|c|c|}
\hline Factors and items & CR & $(\lambda)$ & $(\alpha)$ & AVE & $\begin{array}{l}\text { Exclued } \\
\text { items* }\end{array}$ \\
\hline Market Demand - Cultural Learning Activities (CLA) & 0.91 & & 0.88 & 0.73 & \\
\hline Learning Japanese philosophy (CLAI) & & 0.855 & & & \\
\hline Learning about Japanese culture (CLAZ) & & 0.886 & & & \\
\hline Learning about Japanese heritage (CLA3) & & 0.911 & & & \\
\hline Improve bilingual ability (CLA4) & & 0.761 & & & $x$ \\
\hline Market Demand - Program Activities Offerings (PAO) & 0.85 & & 0.79 & 0.54 & \\
\hline $\begin{array}{l}\text { Opportunity to see master's demonstration performance } \\
\text { (PAO1) }\end{array}$ & & 0.766 & & & $x$ \\
\hline Offers certification from sanctioned organization (PAOZ) & & 0.764 & & & $x$ \\
\hline Child-care services (PAO3) & & - & & & $x$ \\
\hline An appropriate class size (PAO4) & & - & & & $x$ \\
\hline A reasonable belt promotion system (PA05) & & 0.779 & & & $x$ \\
\hline After-school programs (PAO6) & & - & & & $x$ \\
\hline Classes focusing on self-defense (PA07) & & - & & & \\
\hline Quality promotional materials (e.g., pamphlets) (PA08) & & - & & & \\
\hline Opportunities to compete in tournaments (PA09) & & 0.750 & & & $x$ \\
\hline Free trial lessons (PAO10) & & - & & & $x$ \\
\hline Special events (e.g., training camp) (PAO11) & & 0.613 & & & \\
\hline $\begin{array}{l}\text { Various activities for different groups of members } \\
\text { (PAO12) }\end{array}$ & & - & & & \\
\hline Family programs (PAO13) & & - & & & \\
\hline Convenient operating hours (PAO14) & & - & & & $x$ \\
\hline Classes at several different times (PA015) & & - & & & $x$ \\
\hline
\end{tabular}




\section{(Table 1 (Continuation)) \\ LOADINGS OF VARIABLES AND MEASURES OF RELIABILITY AND VALIDITY OF SCALES}

\begin{tabular}{|c|c|c|c|c|c|}
\hline Factors and items & $\mathrm{CR}$ & $(\lambda)$ & $(\alpha)$ & AVE & $\begin{array}{l}\text { Exclued } \\
\text { items* }\end{array}$ \\
\hline Market Demand - Instructional Staff Quality (ISQ) & 0.89 & & 0.85 & 0.58 & \\
\hline Instructors have a good reputation (ISQI) & & 0.755 & & & \\
\hline Having an adequate number of instructors (ISQZ) & & 0.725 & & & $x$ \\
\hline Instructors are willing to help members (ISQ3) & & 0.726 & & & \\
\hline Having well qualified instructors (ISQ4) & & 0.729 & & & \\
\hline Instructors are friendly (ISQ5) & & 0.806 & & & \\
\hline $\begin{array}{l}\text { Instructors handle problems promptly and professionally } \\
\text { (ISQ6) }\end{array}$ & & 0.817 & & & \\
\hline $\begin{array}{l}\text { Market Demand - Physical Facility Quality (PFQ) } \\
\text { (9 items) }\end{array}$ & 0.94 & & 0.93 & 0.65 & \\
\hline The school has first-aid equipment (PFQ1) & & 0.725 & & & $x$ \\
\hline The school has safety equipment (PFQ2) & & 0.756 & & & $x$ \\
\hline The school's facility is safe and comfortable (PFQ3) & & 0.861 & & & \\
\hline The school's interior is well designed (PFQ4) & & 0.870 & & & \\
\hline The school has adequate space for class activities (PFQ5) & & 0.803 & & & \\
\hline The school has up-to-date equipment (PFQ6) & & 0.853 & & & \\
\hline A variety of exercise equipments are available (PFQ7) & & 0.790 & & & $x$ \\
\hline The school's ambience is excellent (PFQ8) & & 0.724 & & & \\
\hline The school's facility is aesthetically attractive (PFQ9) & & 0.852 & & & \\
\hline Market Demand - Locker Room (VES) & 0.92 & & 0.91 & 0.69 & \\
\hline The school offers a good locker room (LRPI) & & 0.890 & & & \\
\hline The locker room is safe (LRPZ) & & - & & & \\
\hline The school offers a good shower room (LRP3) & & - & & & $x$ \\
\hline The locker room in this school is convenient (LRP4) & & 0.845 & & & \\
\hline The locker room in this school is clean (LRP5) & & 0.711 & & & \\
\hline The shower room in this school is clean (LRP6) & & 0.735 & & & $x$ \\
\hline
\end{tabular}




\section{(Table 1 (Continuation)) \\ LOADINGS OF VARIABLES AND MEASURES OF RELIABILITY AND VALIDITY OF SCALES}

\begin{tabular}{|c|c|c|c|c|c|}
\hline Factors and items & CR & $(\lambda)$ & $(\alpha)$ & AVE & $\begin{array}{l}\text { Exclued } \\
\text { items* }\end{array}$ \\
\hline $\begin{array}{l}\text { Market Demand - Economic Condition Consideration } \\
\text { (ECC) }\end{array}$ & 0.92 & & 0.90 & 0.68 & \\
\hline No charge any hidden fees (ECCI) & & - & & & \\
\hline Payment methods service is convenient (ECCZ) & & 0.817 & & & $x$ \\
\hline The membership fee is reasonable (ECC3) & & 0.815 & & & \\
\hline A reasonable refund and cancellation policy (ECC4) & & 0.781 & & & \\
\hline $\begin{array}{l}\text { Offering giveaway items (uniforms, belts, club bag, etc) } \\
\text { (ECC5) }\end{array}$ & & - & & & $x$ \\
\hline Offering flexible payment plans (ECC6) & & 0.889 & & & $x$ \\
\hline Offering optional long term membership category (ECC7) & & 0.795 & & & $x$ \\
\hline Offering discounted family membership option (ECC8) & & 0.836 & & & $x$ \\
\hline Constraints - Intrapersonal Constraints (ITR) & 0.90 & & 0.88 & 0.62 & \\
\hline Health problems (ITRI) & & - & & & $x$ \\
\hline Harder to learn than other sports (ITR2) & & 0.715 & & & $x$ \\
\hline Skills are improved enough (ITR3) & & 0.784 & & & $x$ \\
\hline Tiring to attend the judo school (ITR4) & & 0.840 & & & \\
\hline Afraid of injury (ITR5) & & 0.815 & & & $x$ \\
\hline No fun anymore (ITR6) & & 0.806 & & & \\
\hline Physically challenging (ITR7) & & 0.752 & & & $x$ \\
\hline Constraints - Interpersonal Constraints (ITE) & 0.89 & & 0.84 & 0.68 & \\
\hline Happy with social situations in school (ITEl) & & - & & & \\
\hline $\begin{array}{l}\text { I do not think that the instructor(s)/master is competent } \\
\text { (ITE2) }\end{array}$ & & 0.806 & & & \\
\hline No close partner in school (ITE3) & & 0.835 & & & $x$ \\
\hline $\begin{array}{l}\text { Observing negative attitudes from instructor(s)/master } \\
\text { (ITE4) }\end{array}$ & & 0.794 & & & \\
\hline
\end{tabular}

(continue) 


\section{(Table 1 (Continuation)) \\ LOADINGS OF VARIABLES AND MEASURES OF RELIABILITY AND VALIDITY OF SCALES}

\begin{tabular}{|c|c|c|c|c|c|}
\hline Factors and items & CR & $(\lambda)$ & $(\alpha)$ & AVE & $\begin{array}{l}\text { Exclued } \\
\text { items* }\end{array}$ \\
\hline Constraints - Interpersonal Constraints (ITE) & 0.89 & & 0.84 & 0.68 & \\
\hline $\begin{array}{l}\text { Problems with my training partner in the Judo school } \\
\text { (ITE5) }\end{array}$ & & 0.851 & & & $x$ \\
\hline A language barrier in the Taekwondo school (ITE6) & & - & & & $x$ \\
\hline Constraints - Structural Constraints (STR) & 0.93 & & 0.92 & 0.60 & \\
\hline $\begin{array}{l}\text { Pay for expensive equipments to attend in school } \\
\text { (STRI) }\end{array}$ & & 0.758 & & & \\
\hline $\begin{array}{l}\text { Pay for expensive membership and promotion fees } \\
\text { (STR2) }\end{array}$ & & 0.716 & & & \\
\hline Not enough money to participate in school (STR3) & & 0.782 & & & \\
\hline Not enough time to participate in school (STR4) & & 0.712 & & & \\
\hline The facility is poorly maintained (STR5) & & 0.768 & & & \\
\hline The school is located too far away (STR6) & & 0.826 & & & \\
\hline Not have transportation to attend the school (STR7) & & 0.820 & & & \\
\hline The facility is very crowded (STR8) & & 0.796 & & & \\
\hline I cannot afford to attend the school (STR9) & & 0.797 & & & \\
\hline Psychological Benefit (PB) & 0.91 & & 0.88 & 0.59 & \\
\hline Coping with life's pressures (PBI) & & - & & & $x$ \\
\hline Enhancing self-image (PB2) & & 0.737 & & & \\
\hline Improving my mental health (PB3) & & 0.761 & & & \\
\hline Improving my character (PB4) & & 0.781 & & & \\
\hline Improving positive psychological effect (PB5) & & 0.828 & & & \\
\hline Enhancing self-confidence (PB6) & & 0.820 & & & \\
\hline Feeling better in general (PB7) & & - & & & \\
\hline Improving my appearance (PB8) & & - & & & $x$ \\
\hline Basic athletic skills (PB9) & & - & & & $x$ \\
\hline
\end{tabular}




\section{(Table 1 (Continuation)) \\ LOADINGS OF VARIABLES AND MEASURES OF RELIABILITY AND VALIDITY OF SCALES}

\begin{tabular}{|c|c|c|c|c|c|}
\hline Factors and items & CR & $(\lambda)$ & $(\alpha)$ & AVE & $\begin{array}{l}\text { Exclued } \\
\text { items* }\end{array}$ \\
\hline Psychological Benefit (PB) & 0.91 & & 0.88 & 0.59 & \\
\hline Improving my physical health (PB10) & & - & & & \\
\hline Improving self-protection (PB11) & & - & & & \\
\hline Improving self-defense ability (PB12) & & - & & & \\
\hline Perceived Value - Emotional Value (EMO) & 0.93 & & 0.90 & 0.83 & \\
\hline Something that I would enjoy (EMO1) & & 0.909 & & & \\
\hline Something that I like to participate (EMO2) & & 0.946 & & & \\
\hline I feel comfortable attending the Judo school (EMO3) & & 0.877 & & & \\
\hline Perceived Value - Price Value (PRI) & 0.86 & & 0.76 & 0.67 & \\
\hline Reasonably priced (PRII) & & 0.843 & & & \\
\hline Offering value for the money I spend (PRIZ) & & 0.781 & & & \\
\hline Affordable (PRI3) & & 0.836 & & & \\
\hline Perceived Value - Social Value (SOC) & 0.93 & & 0.89 & 0.82 & \\
\hline Making a good impression on other people (SOCl) & & 0.895 & & & \\
\hline Helping me feel accepted by others (SOC2) & & 0.919 & & & \\
\hline Improving the way I am perceived by others (SOC3) & & 0.905 & & & \\
\hline \multicolumn{6}{|l|}{ Perceived Value - Quality Value (QUA) } \\
\hline Last a long time (QUAI) & & - & & & $x$ \\
\hline I would definitely consider continuing with school (QUAZ) & & - & & & $x$ \\
\hline Member Satisfaction (MAS) & 0.92 & & 0.88 & 0.81 & \\
\hline $\begin{array}{l}\text { I am satisfied with my decision to attend the school } \\
\text { (MSAI) }\end{array}$ & & 0.903 & & & \\
\hline I am happy that I attended the school (MSAZ) & & 0.907 & & & \\
\hline $\begin{array}{l}\text { I think that I did the right thing by deciding to attend } \\
\text { the school }\end{array}$ & & 0.892 & & & \\
\hline
\end{tabular}




\section{(Table 1 (Conclusion)) \\ LOADINGS OF VARIABLES AND MEASURES \\ OF RELIABILITY AND VALIDITY OF SCALES}

\begin{tabular}{l|c|c|c|c|c}
\hline \multicolumn{1}{c|}{ Factors and items } & CR & $(\lambda)$ & $(\alpha)$ & AVE & $\begin{array}{c}\text { Exclued } \\
\text { items* }\end{array}$ \\
\hline \multicolumn{1}{c|}{ Member Commitment (MCO) } & 0.89 & & 0.84 & 0.69 & \\
\hline $\begin{array}{l}\text { I am dedicated to being a member of the school } \\
\text { (MCO1) }\end{array}$ & & 0.857 & & & \\
\hline $\begin{array}{l}\text { I am determined to remain a member of the school } \\
\text { (MCO2) }\end{array}$ & & 0.921 & & & \\
\hline $\begin{array}{l}\text { It would be hard for me to quit member of the school } \\
\text { (MCO3) }\end{array}$ & & 0.836 & & & \\
\hline $\begin{array}{l}\text { I would be willing to do almost anything to keep being a } \\
\text { member of the school (MCO4) }\end{array}$ & & 0.679 & & & $\times$ \\
\hline
\end{tabular}

* From the original study of Kim (2010)

Source: Adapted by the authors from the study of $\operatorname{Kim}(2010)$ and the results of the present study.

Next, we evaluated the discriminant validity, which indicates the level at which a construct differs from the other ones. The test compares the AVE of each construct with the correlations of the squared latent variables, which must have a higher correlation than that of any other construct. A high discriminant validity indicates that the construct is exclusive. One of the methods used to calculate discriminant validity is the Fornell-Larcker test. This method demonstrates how different two constructs are, supposing that each shares a greater variance with its associated indicators than with any other construct (Hair et al., 2009). The data in Table 2 prove the discriminant validity of all constructs and factors. 


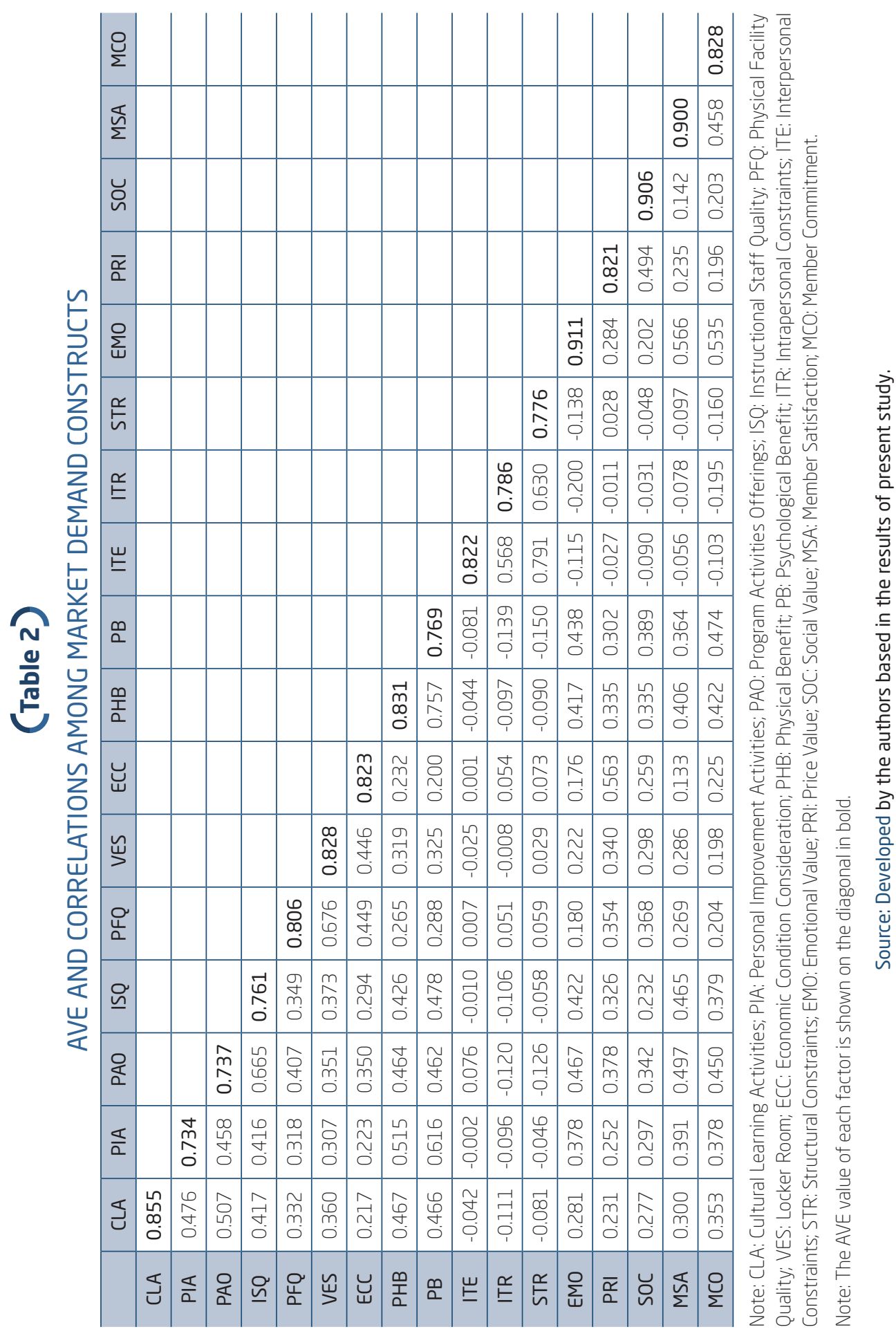




\subsection{Hypothesis Test}

The data presented in Table 3 show that the latent variable, market demand, positively affects perceived benefits $(\beta=0.630 ; t=12.278)$, perceived value $(\beta=0.453 ; t=5.931)$, member satisfaction $(\beta=0.359 ; t=$ 3.955), and member commitment ( $\beta=0.307 ; t=4.530)$, in addition to having a negative impact on perceived restrictions $(\beta=-0.041)$. However, the $t$-value is not statistically significant $(t=0.832 ; p>0.05)$. Thus, in terms of market demand, hypotheses $\mathrm{H}_{1}, \mathrm{H}_{3}, \mathrm{H}_{4}$, and $\mathrm{H}_{5}$ are supported, while $\mathrm{H}_{2}$ is not.

\section{(Table 3)}

HYPOTHESIS TEST

\begin{tabular}{ccccc}
\hline Hypothesis & Direct Effect & Beta $(\beta)$ & t value & P value \\
\hline$H 1$ & Market Demand $\rightarrow$ Perceived Benefits & 0.630 & 12.278 & $<0.01$ \\
\hline H2 & Market Demand $\rightarrow$ Perceived Constraints & -0.041 & 0.832 & $>0.05$ \\
\hline H3 & Market Demand $\rightarrow$ Perceived Value & 0.453 & 5.931 & $<0.01$ \\
\hline$H 4$ & Market Demand $\rightarrow$ Member Satisfaction & 0.359 & 3.955 & $<0.01$ \\
\hline H5 & Market Demand $\rightarrow$ Member Commitment & 0.307 & 4.530 & $<0.01$ \\
\hline$H 6$ & Perceived Benefits $\rightarrow$ Perceived Value & 0.242 & 5.523 & $<0.01$ \\
\hline H7 & Perceived Constraints $\rightarrow$ Perceived Value & -0.059 & 1.653 & $>0.05$ \\
\hline H8 & Perceived Value $\rightarrow$ Member Satisfaction & 0.270 & 2.551 & $<0.05$ \\
\hline H9 & Member Satisfaction $\rightarrow$ Member Commitment & 0.304 & 5.107 & $<0.01$ \\
\hline
\end{tabular}

Source: Adapted by the authors.

We can also see that the effect of perceived benefits on perceived value is positive $(\beta=0.242 ; t=5.523)$ and statistically significant $(p<0.01)$, thus supporting $\mathrm{H}_{6}$. Nonetheless, the results do not support $\mathrm{H}_{7}$. Even though the effects of perceived restrictions on perceived value are negative $(\beta=-0.059)$, they are not statistically significant $(t=1.653 ; p>0.05)$. On the other hand, the relationship between perceived value and satisfaction is positive and statistically significant $(\beta=0.270 ; t=2.551)$, thus supporting $\mathrm{H}_{8}$. Similarly, the results show that satisfaction has a positive impact on members' commitment $(\beta=0.304 ; t=5.107)$, at a significance level of $p<0.01$, supporting $\mathrm{H}_{9}$. 
In the original study (Kim, 2010), the author confirmed support for all hypotheses, other than $\mathrm{H}_{7}$. However, in this study, we did not find support for hypotheses $\mathrm{H}_{2}$ or $\mathrm{H}_{7}$, which predict a negative impact by market demand on restrictions, and a negative impact by restrictions on value, respectively. Both hypotheses relate perceived constraints to market demand and value perception. The theory states that market demand explains the variations in the perceived constraints and that this, in turn, influences the perception of value. In this study, however, the results show that the "perceived constraints" construct should not be used to explain perceptions of value and, consequently, participants' commitment and satisfaction.

Next, we analyzed the $\mathrm{R}^{2}$ of the hypothetical situations, as well as $\mathrm{Q}^{2}$. The determination coefficients, $\mathrm{R}^{2}$, represent the variance in quantity explained by the endogenous constructs in the structural model. Then, $\mathrm{Q}^{2}$ represents the predictive ability of the structural model, which must have a figure over zero (see Table 4).

\section{(Table 4)}

DETERMINATION COEFFICIENTS AND PREDICTIVE ABILITY OF THE ENDOGENOUS VARIABLES

\begin{tabular}{lll}
\hline \multicolumn{1}{c}{ Variable } & $\mathrm{R}^{2}$ & $\mathrm{Q}^{2}$ \\
\hline Market demand & & \\
\hline Perceived Benefits & $0.41^{* *}$ & 0.217 \\
\hline Perceived Constraints & & 0.001 \\
\hline Perceived Value & $0.40^{\star *}$ & 0.166 \\
\hline Member Satisfaction & $0.27^{\star}$ & 0.211 \\
\hline Member Commitment & $0.28^{\star *}$ & 0.185 \\
\hline
\end{tabular}

Note: ${ }^{*} p<0.05^{* \star} p<0.01$

Source: Developed by the authors based in the results of present study.

The constructs that presented a higher variance that can be explained by the market demand were perceived benefit $\left(R^{2}=0.41\right)$ and perceived value $\left(\mathrm{R}^{2}=0.40\right)$. The market demand's ability to predict perceived benefits, value, satisfaction, and commitment, which were created based on the conceptual model, presented $t$-values above the minimum value of 1.96 , with a significance level of $p<0.05$. However, this was not the case for the relation between market demand and restrictions, and between restrictions and value, which presented $t$-values under the required minimum value (Hair et al., 2014). 
It was observed that the $\mathrm{R}^{2}$ values of the endogenous variables (i.e., benefits, value, satisfaction, and commitment) are weak, explaining between $27 \%$ and $41 \%$ of the variance (Hair et al., 2014). On the other hand, the $\mathrm{R}^{2}$ values of the exogenous variables showed greater consistency, ranging from 0.32 for the economic conditions of the market demand construct to 0.90 for the psychological benefits of the perceived benefits construct. The $\mathrm{Q}^{2}$ figures indicate predictive ability, because they were higher than 0 (zero). Nonetheless, because the figures were low, their predictive power is questionable (Hair et al., 2014), highlighting the need of further investigation. The factors with a higher predictive power come from the relationship between perceived restrictions and perceived benefits.

\section{CONCLUSIONS}

Judo is a martial art practiced by thousands of people worldwide, and since 1964, has been part of the Olympic Games. In Brazil, judo is one of the more successful sports in terms of medals, both in the Olympic Games and in the Paralympic Games.

Judo is a well-known and widely disseminated martial art and, thus, attracts thousands of members. However, few studies have focused on understanding the behavior of the sport's participants. Therefore, the current research, based on the work of Kim (2010), proposed adapting and validating a measurement scale in the context of Brazil, an emerging economy.

As a result, this study makes two contributions to the literature. First, we analyze and understand the behavior of judo members, rather than those of other sports, such as tae kwon do, the NBA, the NHL, and the NFL, which have been studied previously (Kim, 2010). Second, we adapt and validate a model initially constructed for the marketing context of a developed country to that of a developing country, such as Brazil. As a result, martial arts managers, and particularly those involved in judo in Brazil, now have an important instrument that can be used to learn about the behavior of new and existing judo practitioners. In addition, this will help when developing incentive policies and maintaining the membership of professional or amateur practitioners in order to ensure the sport continues to grow (Fuller, 1988; Lakes \& Hoyt, 2004; Stefanek, 2004).

With regard to the market demand construct, latent factors (e.g., personal growth activities) were found to be most important $\left(R^{2}=0.56\right)$. Other factors considered important by judo members are self-discipline and improving self-confidence, as well as developing respect for other 
people. Other important latent factors relate to program activities $\left(\mathrm{R}^{2}=\right.$ 0.55), including ranking homologation, a coherent system of belt improvement, and an opportunity to participate in competitions. In the original study, the latent factors that emerged as most important were financial conditions $\left(R^{2}=0.72\right)$ and the quality of teaching staff $\left(R^{2}=0.59\right)$.

Therefore, we may say that Brazilian members are willing to participate in judo to enhance their personal growth, self-discipline, and self-confidence. This result is important for martial arts managers, because they can improve their relationship with (potential) members, using these factors in their strategies and actions to show, for example, how practicing judo can lead to these benefits.

With regard to perceived benefits, a latent factor with two dependent variables was identified (i.e., physical and psychological benefits). This finding differs from those of the original study conducted by Kim (2010). Thus, Brazilian judo practitioners understand that this martial art influences, among other aspects, their self-image, mental health, character, and self-confidence. These findings are supported by the results of other studies, such as Stefanek (2004), Lakes and Hoyt (2004), and the National Sport Diagnostic research conducted by the Brazilian Sport Ministry in 2013. For example, the latter study found that the main reasons Brazilian people participate in sport are to enhance their quality of life and welfare (41.4\%) and to improve their physical performance $(37.8 \%)$. Therefore, managers should consider these physical and psychological benefits when developing (communication) strategies for (potential) judo members.

Then, with regard to perceived restrictions on judo participation, the results indicate that structural restrictions $(\beta=0.944 ; p<0.01)$ are most responsible for people not maintaining their participation in judo training centers. Structural restrictions are related to maintenance, schedule availability, a lack of time (given as the main reason for not doing sport by Brazilian participants in the 2013 National Sport Diagnostic research), a busy schedule, location, and transportation. Interpersonal restrictions $(\beta=0.864$; $p<0.01)$, related to an instructor's attitude and competence, as well as to problems in the training center, have also been identified as factors hindering judo members' participation. Kim's original study (2010) presents intrapersonal and interpersonal restrictions as those that make it more difficult for a member to continue practicing martial arts. Managers need to be concerned about factors that restrict member participation, especially structural problems in the training center, class schedules, the location of the training center in relation to the member's home or work, nearby public transportation, and paying attention to how the staff interact with the members. 
Therefore, having identified the differences between the two studies, the importance of this study becomes evident, because we focus on a new context and a different martial art. In addition, focusing on market demand and the perceived benefits and restrictions will enable training center managers to plan and organize their operations to meet the public's needs.

In addition to those of Kim (2010), the perceived value construct identified three other factors that influence judo practitioners, namely emotional value, price, and social value. This construct is affected positively by market demand and by the perceived benefits of taking part in judo. It also has a positive impact on satisfaction, which encourages practitioners' commitment to the sport.

In summary, we found that market demand positively affects the perceived benefits and value, as well as judo members' satisfaction and commitment. In addition, perceived benefits positively affect perceived value, which then positively affects satisfaction, thus, increasing practitioners' commitment. There is also a negative impact by perceived restrictions on market demand and on perceived value, though neither are statistically significant.

Our results reinforce the relations proposed in Kim's original study, showing a certain solidity in the explanatory power of the underlying theory (Burgess \& Steenkamp, 2006; Sheth, 2011). This theoretical implication is even more important when considering Sheth's statement (2011) that marketing is a subject that modifies itself according to the context in which it is inserted (Sheth, 2011), and that Brazil presents peculiarities inherent to a developing country.

Therefore, we adapted Kim's scale (2010) to the Brazilian judo context and helped to validate it for a developing country. Thus, judo managers may apply the current instrument in order to better understand the main aspects influencing judo members' behavior. A satisfied member will be more committed to the sport, will perceive value, and may even recommend it to others (Eggert \& Ulaga, 2002).

This study has several limitations. First, the age limitation (18 or over) means the findings do not represent the opinions of children and young members between the ages of 8 and 16. Furthermore, the data collection did not follow a probabilistic procedure of selection of respondents. Thus, the results cannot be generalized to the entire population of members of the studied sport. Thus, future studies are necessary to confirm the used model. WSe suggest testing the scale in other sport and fitness segments in order to allow a better generalization of the model and stronger scientific evidence. Another suggestion refers to the analysis of different groups, for example, members that compete versus those who practice the sport as a leisure acti- 
vity. Finally, we suggest a more in-depth analysis of the hypothesis that did not work in this research, but worked in Kim (2010), to ensure this difference did not occur because of study limitations. The mediation of some constructs could be interesting as well.

The martial arts market is competitive, presenting great opportunities to succeed. In order to attract and retain clients, managers must know the market demand, the benefits and restrictions perceived by members, the value they perceive, and the satisfaction that may make them commit and remain in the sport, ensuring their loyalty. It is time to take judo seriously, whether as a member or a sports manager.

\section{DEMANDA DE MERCADO DE ARTES MARCIAIS: TESTE E VALIDAÇÃO DE UM MODELO NO CONTEXTO BRASILEIRO DE JUDÔ}

\section{RESUMO}

Objetivo: Aprofundar o conhecimento dos fatores que determinam e explicam as razões e as intenções dos consumidores e dos praticantes de judô, investigando como suas demandas estão relacionadas a benefícios percebidos, restrições, valor, satisfação e comprometimento dos membros do esporte.

Originalidade/lacuna/relevância/implicações: Testou-se um modelo teórico que especifica as relações direta e indiretamente entre a demanda de mercado e os benefícios, as restrições e o valor percebidos, bem como a satisfação e o comprometimento do praticante de judô com as artes marciais em um país e esporte diferentes do estudo original.

Principais aspectos metodológicos: Realizou-se um levantamento com 328 judocas em academias brasileiras. Os dados coletados foram analisados pelo software PLSmart a partir do método dos Mínimos Quadrados Parciais.

Síntese dos principais resultados: Constatou-se que a demanda de mercado afeta positivamente o valor e os benefícios percebidos e a satisfação e o comprometimento dos membros no judô. Verificou-se também que os benefícios percebidos afetam positivamente o valor percebido o qual afeta positivamente a satisfação, aumentando assim o comprometimento do praticante de judô. 
Principais considerações/conclusões: Os resultados deste estudo reforçam as relações propostas no estudo original de Kim, mostrando força no poder explicativo da teoria subjacente. Mas há também algumas peculiaridades como os benefícios percebidos com a prática do judô e as restrições intrapessoais que desencorajam o envolvimento no judô. Finalmente, este artigo reforça a afirmação de Sheth (2011) de que o marketing se modifica de acordo com o contexto no qual está inserido, neste caso, no judô e no Brasil.

\section{PALAVRAS-CHAVE}

Demanda de mercado. Benefícios. Restrições e valor percebidos. Satisfação. Comprometimento.

\section{DEMANDA DE MERCADO DE ARTES MARCIALES: PRUEBA Y VALIDACIÓN DE UN MODELO SOBRE EL CONTEXTO BRASILEÑO DEL JUDO}

\section{RESUMEN}

Objetivo: Profundizar el conocimiento sobre los factores que determinan y explican las razones e intenciones del consumo de los practicantes de judo, investigando cómo sus demandas en el deporte se relacionan con los beneficios percibidos, las restricciones, el valor, la satisfacción y el compromiso con el judo.

Originalidad/laguna/relevancia/implicaciones: Testamos un modelo teórico que especifica las relaciones directas e indirectas entre la demanda del mercado, los beneficios percibidos, la restricción y el valor, así como la satisfacción y el compromiso del yudoca con las artes marciales en un país y en un deporte diferentes del estudio original.

Principales aspectos metodológicos: Realizamos una encuesta sobre 328 yudocas en gimnasios brasileños. Se analizaron los datos con el software PLSmart que utiliza el método de los mínimos cuadrados parciales.

Síntesis de los principales resultados: Encontramos que las demandas del mercado afectan positivamente los beneficios y el valor percibidos, $\mathrm{y}$ la satisfacción y compromiso de los miembros del judo. También descubrimos que los beneficios percibidos afectan positivamente el valor per- 
cibido, lo que desencadena positivamente la satisfacción, de esta manera aumentando el compromiso del profesional.

Principales consideraciones/conclusiones: Los resultados encontrados en este estudio refuerzan las relaciones propuestas en el estudio original de Kim mostrando cierta solidez en el poder explicativo de la teoría subyacente. Pero hay algunas peculiaridades como diferentes beneficios percibidos para practicar el judo, así como restricciones intrapersonales que desalientan involucrarse en el judo. Finalmente, este artículo refuerza la afirmación de Sheth (2011) de que el marketing se modifica según el contexto en el que se inserta, en este caso, el deporte de judo en Brasil.

\section{PALABRAS CLAVE}

Demanda de mercado. Beneficios. Restricciones y valor percibido. Satisfacción. Comprometimiento.

\section{REFERENCES}

Associação Brasileira de Academias. Retrieved March 03, 2017, from http:// www.acadbrasil.com.br/mercado.html.

Brasil2016. Retrieved March 03, 2017, from http://www.brasil2016.gov.br/ pt-br/paraolimpiadas/modalidades/judo.

Burgess, S. M., \& Steenkamp, J-B. (2006). Marketing renaissance: How research in emerging markets advances marketing science and practice. International Journal of Research in Marketing, 23(4), 337-356. DOI: 10.1016/j. ijresmar.2006.08.001.

Cianfrone, B., Pitts, B. G., Zhang, J., \& Byon, K. (2015). Identifying key market demand factors associated with high school basketball tournaments. Sport Marketing Quarterly, 24(2), 91-104.

Confederação Brasileira de Judô (CBJ). Retrieved December 12, 2015, from www.cbj.com.br/institucional_historia.

Confederação Brasileira de Judô (CBJ). Retrieved March 03, 2017, from http://rdweb.uberflip.com/i/748002-revistacbj16-web.

Cronin, J., Brady, M., \& Hult, G. (2000). Assessing the effects of quality, value, and customer satisfaction on consumer behavioral intentions in service environments. Journal of Retailing, 76(2), 193-218. DOI: 10.1016/S00224359(00)00028-2. 
Dodds, W. B., Monroe, K. B., \& Grewal, D. (1991). Effects of Price, Brand, and Store Information on Buyers Product Evaluations. Journal of Marketing Research, 28(3), 307-319. DOI: 10.2307/3172866.

Easley, R. W., Madden, C. S., \& Dunn, M. G. (2000). Conducting Marketing Science: The Role of Replication in the Research Process. Journal of Business Research, 48(1), 83-92. DOI: 10.1016/s0148-2963(98)00079-4.

Eggert, A., \& Ulaga, W. (2002). Customer perceived value: a substitute for satisfaction in business markets? Journal of Business \& Industrial Marketing, 17(2-3), 107-118. DOI: 10.1108/08858620210419754.

Fornell, C., Johnson, M., Anderson, E., Cha, J., \& Bryant, B. (1996). The American customer satisfaction index: nature, purpose, and findings. Journal of Marketing, 60(4), 7-18. DOI: 10.2307/1251898.

Ferreira, A. UFC faz movimento em academia de artes marciais crescer $80 \%$. Retrieved March 03, 2017, from https://economia.uol.com.br/noticias/ redacao/2013/01/16/donos-de-academias-lucram-com-oferta-de-aulas-delutas-para-fas-do-ufc.htm.

Fuller, J. (1988). Martial arts and psychological health. British Journal of Medical Psychology, (61), 317-328. DOI: 10.1111/j.2044-8341.1988.tb02794.x.

Garbarino, E., \& Johnson, S. M. (1999). The Different Roles of Satisfaction, Trust, and Commitment in Customer Relationships. Journal of Marketing, 63(2), 70-88. DOI: 10.2307/125 1946.

Gotlieb, J., Grewal, D., \& Brown, S. (1994). Consumer satisfaction and perceived quality: complementary or divergent constructs? Journal of Applied Psychology, 79(6), 875-885. DOI: 10.1037/0021-9010.79.6.875.

Hair Jr., F., Black, W. C., Babin, J., Anderson, E., \& Tatham, R. L. (2009). Análise Multivariada de Dados. Porto Alegre: Bookman.

Hair Jr., F., Hult, G. T., Ringle, C., \& Sarstedt, M. (2014). A primer on partial least squares structural equation modeling (PLS-SEM). Los Angeles: SAGES.

Hammond, C. Mito ou verdade: grandes torneios nos incentivam a praticar mais esporte? Retrieved March 03, 2017, from http://www.bbc.com/portuguese/vert-fut-37004003.

Jackson, E. L. (1997). In the eye of the beholder: A comment on Samdahl \& Jekubovich. A critique of leisure constraints: Comparative analyses and understandings. Journal of Leisure Research, 29(4), 458-468.

Jackson, E. L., Crawford, D. W., \& Godbey, G. (1993). Negotiation of leisure constraints. Leisure Sciences, 15(1), 1-11. DOI: 10.1080/01490409309513182. 
Johnson, M., Sivadas, E., \& Garbarino, E. (2008). Customer satisfaction, perceived risk and affective commitment: an investigation of directions of influence. Journal of Services Marketing, 22(5), 353-362. DOI: 10.1108/08876040810889120.

Kim, M. K. (2010). Structural relationships among market demand, perceived benefits, perceived constraints, perceived valeu, member satisfaction, and member commitment toward martial arts participation. PhD Thesis, University of Florida, Gainesville, Florida, USA.

Kim, M. K., Zhang, J. J., \& Ko, Y. J. (2009). Dimensions of market demand associated with Taekwondo schools in North America: Development of a scale. Sport Management Review, 12(3), 149-166. DOI: 10.1016/j. smr.2009.01.003.

Kim, Y. K., \& Trail, G. T. (2010). Constraints and motivators: A new model to explain sport consumer behavior. Journal of Sport Management, 24(2), 190-210. DOI: $10.1123 /$ jsm.24.2.190.

Ko, Y. J. (2004). Current issues and conceptualizations of service quality in the recreational sport industry. Sport Marketing Quarterly, 13(3), 158-166.

Ko, Y. J., \& Yang, J. B. (2012). The Globalization of martial arts: The change of rules for new markets. Revista de Artes Marciales Asiáticas, 4(1), 8-19. DOI: 10.18002/rama.v4i1.222.

Lakes, K. D., \& Hoyt, W. T. (2004). Promoting self-regulation through school-based martial arts training. Journal of Applied Developmental Psychology, 25(3), 283-302. DOI:10.1016/j.appdev.2004.04.002.

Ministério do Esporte. Retrieved March 03, 2017, from http://www.esporte. gov.br/diesporte.

McDougall, G., \& Levesque, T. (2000). Customer satisfaction with services: putting perceived value into the equation. Journal of Services Marketing, 14(5), 392-410. DOI: 10.1108/08876040010340937.

Monroe, K. (2003). Pricing making profitable decisions. Columbus: McGrawHill Irwin.

Monroe, K., \& Krishnan, R. (1985). The effect of price on subjective product evaluations. In Perceived Quality - how consumers view stores and merchandise. Lexington: Lexington Books, 209-232.

Moorman, C., Zaltman, G., \& Deshpandé, R. (1992). Relationship between providers and users of market research: the dynamics of trust within and between organizations. Journal of Marketing Research, 29(3), 314-328. 
Morgan, R. M., \& Hunt, S. D. (1994). The Commitment-Trust Theory of Relationship Marketing. Journal of Marketing, 58(3), 20-39. DOI: 10.2307/1252308. Murphy, P. E., \& Enis, B. M. (1986). Classifying products strategically. Journal of Marketing, 50(3), 24-42. DOI: 10.2307/1251583.

Oliver, R. (1999). Whence consumer loyalty? Journal of Marketing, 63(4), 33-44. DOI: 10.2307/1252099.

Parasuraman, A., \& Grewal, D. (2000). The impact of technology on the quality-value-loyalty chain: a research agenda. Journal of the Academy of Marketing Science, 28(1), 168-174. DOI: 10.1177/0092070300281015.

Shaw, S., Bonen, A., \& McCabe, J. (1991). Do more constraints mean less leisure? Examining the relationship between constraints and participation. Journal of Leisure Research, 23(4), 286-300.

Sheth, J. N. (2011). Impact of Emerging Markets on Marketing: Rethinking Existing Perspectives and Practices. Journal of Marketing, 75(4), 166-182. DOI: 10.1509/jmkg.75.4.166.

Snoj, B., Korda, A. P., \& Mumel, D. (2004). The relationships among perceived quality, perceived risk and perceived product value. Journal of Product \& Brand Management, 13(3), 156-167. DOI: 10.1108/10610420410538050.

Stefanek, K. A. (2004). An exploration of participation motives among collegiate taekwondo participants. Unpublished doctoral dissertation, Michigan State University, East Lansing, 2004.

Sweeney, J., \& Soutar, G. (2001). Consumer perceived value: the development of a multiple item scale. Journal of Retailing, 77(2), 203-220. DOI: $10.1108 / 17506121211243086$.

Tam, J. (2004). Customer satisfaction, service quality and perceived value: an integrative model. Journal of Marketing Management, 20(7), 897-917. DOI: 10.1362/0267257041838719.

Tse, G. K., \& Wilton, P. C. (1988). Models of consumer satisfaction formation: an extension. Journal of Marketing Research, 25(2), 204-212. DOI: $10.2307 / 3172652$.

Ulaga, W., \& Chacour, S. (2001). Measuring customer perceived value in business markets. Industrial Marketing Management, 30(6), 525-40. DOI: 10.1016/S0019-8501(99)00122-4.

Woodruff, R. (1997). Customer value: the next source for competitive advantage. Journal of the Academy of Marketing Science, 25(2), 139-153. DOI: 10.1007/BF02894350. 
Zeithaml, V. A. (1988). Consumer perceptions of price, quality, and value: a means-end model and synthesis of evidence. Journal of Marketing, 52 (3), 2-22. DOI: $10.2307 / 1251446$.

Zeithaml, V. A., Berry, L. L., \& Parasuraman, A. (1990). Delivering Quality Service. New York: The Free Press.

Zhang, J. J., Pease, D. G., Hui, S. C., \& Michaud, T. J. (1995). Variables affecting the spectator decision to attend NBA games. Sport Marketing Quarterly, 4(4), 29-39.

Zhang, J. J., Lam, E. T. C., \& Connaughton, D. P. (2003). General market demand variables associated with professional sport consumption. International Journal of Sports Marketing and Sponsorship, 5(1), 33-55. DOI: 10.1108/ IJSMS-05-01-2003-B003. 